\title{
SOME TRENDS IN ENERGY POLICY \\ IN KAZAKHSTAN
}

\author{
DIANA ISMAILOVA
}

Sofia St. Kliment Ohridsky University, Bulgaria,

Kokshe Academy, Kazakhstan

\section{ABSTRACT}

This research first deals with the states of affairs Kazakhstan faces nowadays in the field of energy security. Energy security is a declared priority for Kazakhstan government. The article explores the diverse risks that may arise from conditions of increasing economic competition and resource scarcity, and the full range of problems that may follow if major producers or consumers of energy lose confidence to secure access to energy. It surveys the strategic outlook of both producer and consumer states.

Oil, which sits in the foreground of the global energy picture, is a finite resource. Much remains to be discovered about the ultimate extent of global petroleum reserves, and about the economics of their exploitation. [1]

\section{JEL CLASSIFICATION \& KEYWORDS}

- F59 | Energy Security | Energy Policy

\section{INTRODUCTION}

One of the main themes of this report is that energy security is major challenge facing both consumers and producers. In order to maintain economic prosperity and political stability, the two sides need to further improve their cooperation and expand the joint institutions and programs already in place. In the late 2000s global demand for energy was reduced substantially and, as a result, fuel prices fell. The main reason behind this availability of supplies at low prices was the global recession. This temporary development should be seen in the right context. As the world economy recovers, the demand for energy will grow and prices will rise. For the long-term efforts to enhance global energy security a number of dynamics should be taken into consideration.

First, in the last few decades consuming and producing countries have been going in opposite directions. Most governments in consuming nations have reduced their role in the broad economic system, including the energy sector. Their role emphasizes providing incentives and regulations rather than active participation. Meanwhile, governments in most producing countries have achieved a little success in privatizing their public enterprises and still play a significant role in their economies, particularly the energy sector. Lessons from the global recession in the late 2000 s are yet to be drawn. Nevertheless, efforts to enhance energy security, at both national companies need to work together.

Second, for domestic political consumption, some policymakers in consuming countries keep talking about "energy independence". These calls for energy independence were made in the early 1970s and have been proven unrealistic. In the twenty-first century all world economies are interconnected. Within the context of a global economy there is no room for "independence" in any commodity, energy or otherwise.

Third, for most of the decades following the first oil shock (1973-1974) energy security was largely the outcome of rivalry between consuming countries represented by the IEA and producing nations represented by OPEC. Asia's fast- growing economies (i.e, China and India) are not members of either IEA or OPEC. Beijing and New Delhi have reshaped the global energy landscape since the early 2000s. Their role and leverage are projected to grow. Both OPEC and IEA have approached China and India and sought to "engage" them and deepen cooperation with the two Asian giants. More is needed. Both nations have become major energy consumers and polluters. They need to be incorporated more politically and institutionally into the global energy system. [2, 2]

Finally, fossil fuels, particularly oil, have continued to dominate the global energy mix. Little wonder that political negotiations and the energy security and oil security meant largely the same thing. In recent years, oil security, though $\mathrm{d}$ in important, has increasingly become only a part of the broader energy security. Other sources of energy such as nuclear power, coal, natural gas, and particularly renewable sources, as well as efficiency and conservation, constitute important parts of the energy security story.

\section{Energy policy in Kazakhstan}

In the last few decades energy security has evolved from a zero-sum game where the producers' gains were seen as the consumers' losses to a win-win opportunity where cooperation and accommodation have replaced the oil notions. Global energy security is likely to further improve by taking a more inclusive approach, under which all energy players (public and private, producers and consumers) work together in a more cooperative fashion.

Kazakhstan holds the largest proven oil reserves in the Caspian Sea (39,8 billion barrels, 3,2\% of the world's total) and has the potential, or indeed is already on its way, to become a major oil producer. Oil was first found in Kazakhstan in 1899 and was first produced in 1911. Oil production from Kazakhstan (and Azerbaijan) was the backbone of the Soviet oil industry until fields in western Siberia went onstream in the 1960. Like Azerbaijan, shortly after independence Kazakhstan invited foreign investment to revive its oil industry. These investors signed agreements with the then national company KazakhOil. In March 2004 the company was renamed Joint Stock Company KazMunaiGAz National Company (KMG). It was created to pursue a comprehensive development of the country's petroleum industry and to ensure rational and efficient operation of hydrocarbons. As in other oil countries, one of KMG's goals is to create jobs for the Kazakhs in their growing oil and gas industry. The company has stakes virtually all major and gas projects in the country. The first and biggest joint venture involving foreign oil companies, TengizChevrOil was established in 1993.

The majority of growth in Kazakhstan oil production is projected to come from mainly four enormous fields: Karachaganak, Kurmangazy, Tengiz, Kashagan, particularly the last two.

President Nursultan Nazarbayev signed an amendment into law in October 2007 that allows the government to unilaterally break contracts with oil companies. Another amendment to the country' subsoil law in 2005 extended

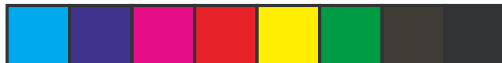




\section{SOME TRENDS IN ENERGY POLICY IN KAZAKHSTAN}

the government's power to buy back energy assets by limiting the transfer of property rights to strategic assets in Kazakhstan.

Kazakhstan holds much smaller proven natural gas reserves $(1,82$ billion cubic meters or $1,0 \%$ of the world's total) and in 2010 it produced 32,2 billion cubic meters or $1 \%$ of the world's total. Four characteristics of the Kazakh natural gas industry can be identified:

1. Almost all of the country's gas is "associated" gas found in oil fields. Most of the Kazakh gas produced from two major oil fields: Tengiz and Karachaganak.

2. Much of the gas ir reinjected in oil fields to maintain reservoir pressure and enhance oil output. Gas is also used in power generation but on a small scale.

3. As in some other countries, natural gas was largely unutilized. Indeed, much of the Kazakh gas was being flared and the country was one of the largest gas flares in the world. Since 2005 the government has ordered oil companies to avoid natural gas flaring.

4. Much of the gas is produced in the western part of the country, while the main consumption centers are in the south. As a result, these population and industrial centers in the south depend on imported gas suppliers. Since 2007 Kazakhstan has been exporting a small volume of natural gas. [2, 134]

Our civilization experiences a qualitatively new stage, both correlation and interdependence strengthen. We are thinking over the ways of future development for we accept the necessity of a universal model of well- balanced coexistence at our planet. The base of the vital activity of our planet is energetics. That is why the issues relating to the energy preparedness are essential for any of future existence model. XXI will see an inevitable growth of power consumption due to the growing economy of the developing countries. As a result we will witness the development of a resource base of the global power industry. Today, more than $80 \%$ of the energy resources consumed consist of the following organic, fossil fuels: coal, oil, gas. In spite of the active steps aiming at the implementation of new power resources, the second half of the XXI century will have these resources as key ones for the global power industry. Energy preparedness is the opposite notion to, what we call, national energy egoism, which can be of common practice both by the production countries, consumption countries and the countries with their economy in transition. The power market has become of a global rank for a long period of time. That is why we are talking about the global energy preparedness rather than the national security of "the favorite countries". The structure of the present global power market and the degree of its integrity make impossible the reliability due to the misbalance of the global power system. Power saving is considered to be a high- priority direction for the national policy of many countries for more than thirty last years. The implementation of power saving activities shows that the following factors can satisfy the demands of the global community and consequently stable global development: the rational usage and saving of such organic fuel resources as coal, oil and natural gas, upgrading of the final consumption at all the economic sectors, development of the renewable energy sources and other resources. Power usage is of fundamental importance for the social and economic development, improvement of such areas as: living standards, accommodation, transportation means, and facilitation of labor, etc. The large- scale and increasing power consumption has always been one of the fundamentals both in the production and consumption of the products. In some of the countries such factors as environment damage, harm to the human health caused by the power production are at the warning stage. Both power production and usage is connected with the following substantive problems and restrictions:

\section{- Environment damage}

- Air and water pollution, wastes generation, accidents

- Land cession and disfigurement of a landscape, soil degradation and desertification, etc.

- Requirement of the national and foreign investments to insure the national production scope and energy sources import demanded

- Political risks connected with the strategic, geopolitical and military importance of the certain power sources

Now we know for sure that the era of chip power sources has come to the end. Exploration and exploitation of new fields takes more money. The ecological restrictions connected with the environmental effect from burning of the organic fuel are becoming very strict. Power security in Eurasia depends on such factors as: resources of the countries in the region, economic availability of power resources, ecologic and technologic validity of their usage. Assurance of power security became the most important issue of the European Union agenda, which has the biggest power resources delivery among the regions of the world, approximately $16 \%$ of the global market. Here are the problems aggravating the problems of the power balance preservation: inevitable depletion of hydrocarbon sources, results of the global climate changing, quick growth of the power sources prices. The main risks for the power security assurance in Eurasia are the uncovered demand for the power resources coupled with the geographical irregularity, fuel and power demand and supply imbalance. Insufficient level of power transport infrastructure prevents from the stabilization of the demand and supply by means of international power sources market and results in the instability of the prices. Both the overheating of the thriving economics of the Asian countries and ailing of the innovational energetics of the main of the fuel and power oriented European countries also prevent from the factor mentioned above. To define these risks and ensure power preparedness of the countries in the region it is necessary to develop power and transport infrastructure of Eurasia, first of all on the territory of Kazakhstan and Central Asia. It could facilitate the international trade, international power and transport projects, investments which are restrained by the political and economical risks. Both the increase of the informational transparency of the Eurasian power sector and recognition of the mutual standard are the main condition for the agreement of the power programs and policies of the import and export countries. One of the most important parts of the power preparedness is the ecological stability. This problem requires its consideration when working out of the power programs and projects. The causes of such approach application are the following: the significant impact of the power sector on the environment, on one hand increasing role of this sector in the economy, upon the other hand new ecologic problems.

Taking into consideration the ecological factor, power preparedness should consist of three components:

- Stable power supply for the own development

- The policy of "double reward", which allows getting the maximal economical profits from the power resources under the improvement of the ecological situation

- Lessening of the ecologic influence of the power sector

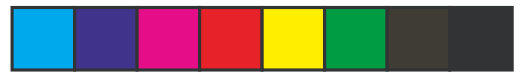


There is no sense in the artificial growth rate reduction under the present social and economical situation in the country. However, it is necessary to increase the effectiveness of this sector. The energetics development is closely connected with the primary global ecological problems, so, there is a necessity to explain the choice from two options of the natural capital of Central Asia such as: resourceful, supplying the Central Asian countries and the whole world with the power resources and ecosystem resources which support the biosphere of the planet.

In the last time Kazakhstan witnessed an economic boom conducted by hasty growth of consumption of electric and heating energy. However, our energy system was created in the Soviet period and reached the end of its opportunity. Having realized coming issues our government intended to lead a large-scale modernization of current project reconstruction in 2015-2030. In the beginning of November Iteca Company organized PowerKazakhstan 2008 conference, the Ministry of Energy confirmed that despite of world financial crisis and aroused inner problems, plans of Kazakhstan in developing industry are unchangeable.

Secretary of State of the USA Candolisa Rise visited Kazakhstan in October, 2005, she was impressed by beauty and a large-scale project constructions in Astana, a new capital of our state. «l found myself on the island of stability which can be supported by the development of the whole Central-Asian region» declared an important visitor. [3]

Kazakhstan is a single country which is called a main partner and allied member, even «a single strong allied member» both in the USA, Russia and also in China and India. Perhaps, no countries have not reached yet such a great diplomatic achievements for the last years and have no such relationships with all important countries in the world.

Achievements of Kazakhstan are great and undeniable. After fall and crisis aroused by collapse of the USSR in 1991-1996, Kazakhstan managed to raise faster the whole Commonwealth of Independent States and to provide a steady progress to the whole directions. Yearly growth of GDP output in Kazakhstan amounted about 10\% per annum in 2000-2005. In 2005 only Kazakhstan and Belorussia exceeded production level and rate of GDP per capita which was obtained in 1990.

Taking into consideration the estimation of the World Bank, Kazakhstan enters the list of twenty states attracting investments and playing a great role among the developed countries. Investors like stability of the state and Kazakhstan is considered to be a responsible and reliable supplier of energy resources which makes a great contribution to the energetic balance of world economy. According to experts' opinion Kazakhstan have a high potential for a further development of energetic resources. Especially great demand for Kazakhstani oil exists in China. KazakhstanChina petroleum pipeline is the first pipeline of China history which connects it with the foreign reserves of oil.

\section{Conclusion}

The basis of Kazakhstan economy today is the oil industry. It is oil prospecting and oil production. It is oil processing into the petrol and other products. There are also oil and gas equipment, pipelines, tankers manufacturing and oil pumping stations service. Major part of foreign investments goes to the oil and gas industry of Kazakhstan. Oil is the main wealth of Kazakhstan. Oil is the main source of many problems of the Kazakhstan society.

Growth of the world economy and economy of Asian countries is conducted by substantial increase of energy resources consumption, improvement of competition on the market outlets and electric energy consumption. The contest of leading world players is aggravated in oil and gas sector in order to have access to the hydro carbonic resources of Central Asia. There appeared a sense in assuring the power preparedness of the countries by means of creation of the regional power markets. At the same town, the power preparedness becomes more and more political issue. Asian power policy is to bring to minimum this political influence and be based on the economical priority principles only. The Asian power strategy is to facilitate the economical growth of the countries in the region. Power market integration demands the development of the transparency for the power policy of the participating countries. Here are the steps to take in order to make the power market transparent and liberalize it: creation of the mutual information fund and free access to it, creation of the mutual electronic power stock exchange including electric and power, oil, gas and coal stock exchanges.

Kazakhstan Republic's development strategy till 2030 contains the domination of the energy direction. Three main directions determined in this strategy are:

1. Kazakhstan Republic's fluent promotion to the world energy markets by means of the involvement of foreign oil monopolies to gas-oil projects, foreign business circles, big investments and the best world technologies.

2. Creating the system of export pipelines for gas and oil transportation in order that it should be possible to liquidate the transport and monopolistic price dependence from the consumers.

3. The strategy of the state upon the using the fuel resources determines the interest of the world community countries to Kazakhstan as to the supplier of energy feedstock.

Kazakhstan Republic's foreign-policy strategy in the sphere of energy determines the great involvement of foreign investments for the guarantee of the country safety. [4]

The aim of energy policy is the maximum effective use of nature fuel energy resources and potential of energy sphere for the development of economics and improvement of the quality of the country population life, determination by the way of the progress to the qualitatively new condition of fuel energy complex, the development of competitiveness of its products and services in world market, based on using the potential and determination of priorities of complex development, measures and mechanisms of state energy policy accounting the future results of its realization.

\section{REFERENCES}

1. Daniel Moran and James A. Russel. Energy Security and Global Politics. The Militarization of resource management, Raylor \& Francis Group, NY, 2009

2. Gawdat Bahgat, Energy security - An Interdisciplinary Approach, A John Wiley and Sons, Ltd, Publication, Washigton DC, USA, 2011, pp. 142-145

3. Energy security and Global Politics, The militarization of resource management., Routledge Taylor \& Francis Group, London and New York, 2009

4. N.A. Nazarbayev, Program 2030 .- Almaty, 1998. 